\title{
Acknowledgment to Reviewers 2016
}

\author{
Dijana Vuletić ${ }^{1}$, Ivan Balenović ${ }^{2 *}$
}

(1) Editor-in-Chief of South-east European forestry Journal, Croatian Forest Research Institute, Common Affairs Service, Cvjetno naselje 41, HR-10450 Jastrebarsko, Croatia; (2) Managing Editor of South-east European forestry Journal, Croatian Forest Research Institute, Division for Forest Management and Forestry Economics, Trnjanska cesta 35, HR-10000 Zagreb, Croatia

Citation: VULETIĆ D, BALENOVIĆ | 2017 Acknowledgment to Reviewers 2016. South-east Eur for 8 (1): 69-70. DOI: https://doi.org/10.15177/seefor.17-03

* Correspondence: e-mail: seefor@sumins.hr

Published online: 15 Mar 2017

The editors of South-east European forestry would like to express their sincere gratitude to the following reviewers for evaluating manuscripts in 2016. Their generous contributions of time and expertise are greatly appreciated.

Ballian, Dalibor; University of Sarajevo, Faculty of Forestry (Sarajevo, Bosnia and Herzegovina)

Dukić, Vojislav; University of Banja Luka, Faculty of Forestry (Banja Luka, Bosnia and Herzegovina)

Bocanegra Gonzalez, Kelly Tatiana; Universidad del Tolima, Grupo de Investigación en Biodiversidad y Dinámica de Ecosistemas Tropicales (Ibagué, Colombia)

Fadhlullah, Muhammad; Bandung Institute of Technology, School of Life Sciences and Technology (Bandung, Indonesia) Ferreras, Ana; National University of Cordoba, Institute for Multidisciplinary Plant Biology (Cordoba, Argentina)

Gallis, Christos; Forest Research Institute (Thessaloniki, Greece)

Giuffrè, Angelo Maria; Mediterranean University of Reggio Calabria, Department of Agricultural Science (Reggio Calabria, Italy)

Gulsrud, Natalie; University of Copenhagen, Department of Geosciences and Natural Resource Management (Copenhagen, Denmark)

Hanzu, Mihail; National Institute for Research and Development in Forestry "Marin Drăcea" (Voluntari, Romania)

Indir, Krunoslav; Croatian Forest Research Institute (Jastrebarsko, Croatia)

Jakovljević, Tamara; Croatian Forest Research Institute (Jastrebarsko, Croatia)

Jelić, Goran; Institute for Adriatic Crops and Karst Reclamation (Split, Croatia)

Jurc, Dušan; Slovenian Forestry Institute (Ljubljana, Slovenia) Kiprovski, Biljana; Institute of Field and Vegetable Crops (Novi Sad, Serbia)

Klepo, Lejla; University of Sarajevo, Faculty of Science (Sarajevo, Bosnia and Herzegovina)

Knapic, Sofia; Universidade de Lisboa, Instituto Superior de Agronomia, Centro de Estudos Florestais (Lisbon, Portugal)

Krč, Janez; Universitiy of Ljubljana, Biotechnical Faculty, Department of Forestry and Renewable Forest Resources (Ljubljana, Slovenia)

Levanič, Tom; Slovenian Forestry Institute (Ljubljana, Slovenia)
Ozarska, Barbara; University of Melbourne, School of Ecosystem and Forest Sciences (Burnley, Melbourne, Australia)

Nagaike, Takuo; Yamanashi Forest Research Institute (Fujikawa, Yamanashi, Japan)

Malvolti, Maria Emilia; National Research Council of Italy (CNR), Institute of Agro-Environmental and Forest Biology (IBAF) (Porano, Italy)

Matošević, Dinka; Croatian Forest Research Institute (Jastrebarsko, Croatia)

Mattijssen, Thomas; Wageningen University, Forest and Nature Conservation Policy Group (Wageningen, The Netherlands)

Medak, Jasna; Croatian Forest Research Institute (Jastrebarsko, Croatia)

Mikac, Stjepan; University of Zagreb, Faculty of Forestry (Zagreb, Croatia)

Moya, Laura; Universidad ORT Uruguay, Faculty of Architecture (Montevideo, Uruguay)

Ofomondi, Stephen; Moi University, Department of Forestry and Wood Science Technology (Eldoret, Kenya)

Pach, Maciej; University of Agriculture in Krakow, Faculty of Forestry (Krakow, Poland)

Palčić, Igor; Institute of Agriculture and Tourism (Poreč, Croatia)

Panayotov, Momchil; University of Forestry, Forestry Faculty (Sofia, Bulgaria)

Pekeč, Saša; Institute of Lowland Forestry and Environment (Novi Sad, Serbia)

Perić, Sanja; Croatian Forest Research Institute (Jastrebarsko, Croatia)

Perković, Ivan; University of Zagreb, Faculty of Forestry (Zagreb, Croatia)

Petek, Marko; University of Zagreb, Faculty of Agriculture (Zagreb, Croatia)

Petrović, Slavica; University of Belgrade, Faculty of Forestry (Belgrade, Serbia)

Poljanšek, Simon; Slovenian Forestry Institute (Ljubljana, Slovenia) 
Potočić, Nenad; Croatian Forest Research Institute (Jastrebarsko, Croatia)

Seletković, Ante; University of Zagreb, Faculty of Forestry (Zagreb, Croatia)

Socha, Jaroslaw; University of Agriculture in Krakow, Department of Biometry and Forest Productivity (Krakow, Poland)

Stojanović, Dejan; Institute of Lowland Forestry and Environment (Novi Sad, Serbia)

Stojnić, Srđan; Institute of Lowland Forestry and Environment (Novi Sad, Serbia)
Teslak, Krunoslav; University of Zagreb, Faculty of Forestry (Zagreb, Croatia)

Trudić, Branislav; Institute of Lowland Forestry and Environment (Novi Sad, Serbia)

Qiu, Jiangxiao; University of Wisconsin-Madison, Department of Zoology, Ecosystem and Landscape Ecology Lab (Madison, Wisconsin, USA)

Ugarković, Damir; University of Zagreb, Faculty of Forestry (Zagreb, Croatia)

Vilhar, Urša; Slovenian Forestry Institute (Ljubljana, Slovenia) 